\title{
Crystal structure of DyAg $\operatorname{In}_{3}$
}

\author{
Marta DEMCHYNA $^{1 *}$, Bohdana BELAN ${ }^{1}$, Mykola MANYAKO $^{1}$, Lev AKSELRUD $^{1}$, Antonio CERVELLINO ${ }^{2}$, \\ Viktor HLUKHYY ${ }^{3}$, Yaroslav KALYCHAK ${ }^{1}$ \\ ${ }^{1}$ Faculty of Chemistry, Ivan Franko National University of Lviv, \\ Kyryla i Mefodiya St. 6, UA-79005 Lviv, Ukraine \\ ${ }^{2}$ Swiss Light Source, Paul Scherrer Institute, CH-5232 Villigen, Switzerland \\ ${ }^{3}$ Department of Inorganic Chemistry, Technical University of Munich, \\ Lichtenberg St. 4, D-85747 Garching, Germany \\ * Corresponding author: E-mail: marta.dem.85@gmail.com
}

Received September 22, 2010; accepted October 29, 2010; available on-line March 2, 2011

The DyAg $\mathrm{In}_{3}$ compound was prepared by arc-melting of pure compact metals under an argon atmosphere. The crystal structure was refined from synchrotron powder diffraction data (space group Im-3, $a=15.1472(2) \AA, Z=24, R_{p}=0.0792, R_{w p}=0.1031, R_{e x p}=0.0231$, refined composition DyAg $\left.\mathbf{g}_{3.010} \operatorname{In}_{3}\right)$ and from conventional $X$-ray single crystal diffraction data $\left(a=15.1010(1) \AA, R=0.0423, R_{w}=0.0433\right.$, refined composition $\mathrm{DyAg}_{2.85} \mathrm{In}_{3}$ ). The crystal structure belongs to the $\mathrm{YbAg} \mathrm{In}_{4}$ structure type, which is closely related to the structures of $\mathrm{YbCd}_{6}$ and $\mathrm{YCd}_{6}$.

Dysprosium/ Silver / Indium / Crystal structure / X-ray single crystal diffraction / Synchrotron X-ray diffraction

\section{Introduction}

Ternary compounds of rare-earth metals $(R E)$ with $3 d$-metals and indium have recently attracted the attention of researchers, due to their interesting physical, mainly magnetic and electrical, properties [1]. The corresponding systems with $4 d-, 5 d$ - and noble metals are less studied, but several papers dedicated to them and their compounds have appeared the last years [2-11].

In an earlier examination of the $\mathrm{Yb}-\mathrm{Ag}-\mathrm{In}$ system, the existence of the $\mathrm{YbAg}_{2} \mathrm{In}_{4}$ compound, which crystallizes in its own structure type, was discovered and its crystal structure and physical properties were investigated [12]. The compound has a relatively complex structure with a large lattice constant ( $a=15.324 \AA$ ). The structure is defective with silver atoms occupying split-positions and is closely related to the binary intermetallides $\mathrm{YCd}_{6}$ [13] and $\mathrm{YbCd}_{6}$ [14]. A comparative analysis of the crystal structures of these compounds can be found in [12]. New representatives of the structure type are described in [15-18]. Phases with local pseudoicosahedral structure were found at the composition $R E_{16} \mathrm{Ag}_{42} \mathrm{In}_{42}$ $(R E=\mathrm{Gd}, \mathrm{Tb}, \mathrm{Dy}, \mathrm{Ho}, \mathrm{Er}, \mathrm{Tm}, \mathrm{Yb}$ and $\mathrm{Lu})$ in [17]. Thermal and electrical properties of quasicrystals of the $\mathrm{Yb}-\mathrm{Ag}-\mathrm{In}$ system were studied in [18]. An X-ray single crystal investigation of the $\mathrm{TbAg}_{3} \mathrm{In}_{3}$ compound, isostructural with $\mathrm{YbAg}_{2} \mathrm{In}_{4}$, was performed in [19]. Formation of similar compounds has been revealed in several $R E-\mathrm{Ag}-\mathrm{In}$ systems $(R E=\mathrm{Ce}, \mathrm{Pr}, \mathrm{Eu}, \mathrm{Gd}, \mathrm{Tb}, \mathrm{Dy}, \mathrm{Er}, \mathrm{Tm})$ [20] and an $\mathrm{X}$-ray diffraction analysis of complex metallic alloys has been carried out for the Eu-Ag-In system [21]. Recently, a new series of $R E \mathrm{Pd}_{2} \mathrm{In}_{4}$ compounds $(R E=\mathrm{Sm}, \mathrm{Gd}-\mathrm{Ho})$ with $\mathrm{YbAg}_{2} \mathrm{In}_{4}$ structure type was found [22].

During an investigation of the phase equilibria in the Dy-Ag-In system at $870 \mathrm{~K}$ the existence of a ternary compound of composition $\mathrm{DyAg}_{\sim 3} \operatorname{In}_{3}$ was confirmed. The determination of the crystal structure of this compound by means of conventional X-ray single crystal diffraction and synchrotron powder diffraction is the object of this work.

\section{Experimental}

Samples for the investigation were prepared by arc melting under an argon atmosphere (purified with a titanium getter) from compact metals of high purity: Dy 99.8 wt.\%, Ag 99.98 wt.\%, and In 99.999 wt.\%. Homogeneous annealing was performed at $870 \mathrm{~K}$ for one month. High-resolution powder diffraction data were collected for an annealed alloy of composition $\mathrm{Dy}_{15} \mathrm{Ag}_{43} \mathrm{In}_{42}$ at room temperature $(0.5 \mathrm{~mm}$ glass capillary). Synchrotron radiation (Materials Science Beamline at the SLS, PSI; silicon strip detector 
Table 1 Experimental and crystallographic data for $\operatorname{DyAg}_{\sim 3} \operatorname{In}_{3}$.

\begin{tabular}{|c|c|c|}
\hline & $\begin{array}{l}\text { Synchrotron X-ray powder } \\
\text { diffraction }^{\text {a }}\end{array}$ & $\begin{array}{l}\text { X-ray single crystal } \\
\text { diffraction }\end{array}$ \\
\hline Composition & $\operatorname{DyAg}_{3.010} \operatorname{In}_{3}$ & $\mathrm{DyAg}_{2.853} \mathrm{In}_{3}$ \\
\hline$M r, \mathrm{~g} \mathrm{~mol}^{-1}$ & 831.634 & 814.701 \\
\hline Structure type & $\mathrm{YbAg}_{2} \mathrm{In}_{4}$ & $\mathrm{YbAg}_{2} \operatorname{In}_{4}$ \\
\hline Space group & Im-3 (204) & Im-3 (204) \\
\hline$Z ;$ Pearson code & $24 ; c I 168.240$ & $24 ; c I 164.472$ \\
\hline Lattice parameter, $\AA$ & $a=15.1472(2)$ & $a=15.1010(1)$ \\
\hline Cell volume, $\AA^{3}$ & $3475.3(2)$ & $3443.64(7)$ \\
\hline Crystal size, $\mu \mathrm{m}^{3}$ & - & $\sim 120 \times 80 \times 15$ \\
\hline Color & metallic dark gray & metallic dark gray \\
\hline Calculated density, $\mathrm{g} \mathrm{cm}^{-3}$ & $9.5438(4)$ & $9.4238(2)$ \\
\hline Radiation type; wavelength, $\AA$ & synchrotron; 0.49063 & Mo K $\alpha ; 0.71073$ \\
\hline Absorption coefficient, $\mathrm{mm}^{-1}$ & 383.49 & $\begin{array}{l}341.33 \\
-19 \leq h \leq 22\end{array}$ \\
\hline Range in $h k l$ & - & $\begin{array}{l}-22 \leq k \leq 23 \\
-23 \leq l \leq 22\end{array}$ \\
\hline Reflections collected/unique & - & $1159 / 791$ \\
\hline $2 \theta_{\min }-2 \theta_{\max }, \mathrm{deg}$ & $2.59-76.89$ & $6.60-65.74$ \\
\hline Refinement method & full profile & full-matrix least-squares \\
\hline Refined parameters & 65 & 44 \\
\hline Goodness-of-fit on $F^{2}$ & - & 1.06 \\
\hline Final $R$ indices $[I>2 \operatorname{sigma}(I)]$ & $\begin{array}{l}R_{p}=0.0792, R_{w p}=0.1031 \\
R_{B}=0.178\end{array}$ & $R_{I}=0.0423, R_{w}=0.0433$ \\
\hline
\end{tabular}

a Impurities: 2 - DyIn 3 phase (18.92 wt.\%, AuCu -type, space group Pm-3m, a= 4.5364(2) $\AA$ ), $3-\mathrm{Ag}_{7} \mathrm{In}_{3} \mathrm{phase}^{\mathrm{a}}$ (2.73 wt.\%, Mg-type, space group $P 6_{3} / m m c, a=3.0044(4), c=4.7668(4) \AA$ ).

MYTHEN II) with a wavelength of $\lambda=0.49063 \AA$ was used. The diffractometer was calibrated with an external silicon standard.

A single crystal of irregular shape was selected mechanically from the same alloy. Single crystal diffraction data were collected on an Xcalibur 3 diffractometer (Oxford Diffraction) equipped with a monochromatic Mo $\mathrm{K}_{\alpha}$ source $(\lambda=0.71073 \AA)$. The exposure time was $80 \mathrm{~s}$ per frame. The collection of intensity data was carried out with the CrysAlis program. The final lattice parameters were calculated from all the observed reflections in the actual data collection. The structure was solved by direct methods, and refined by using the WinCSD program package [23]. The crystallographic data and details of the data collection are listed in Table 1.

The single crystal investigated on the diffractometer was also studied by energy-dispersive X-ray analysis (EDX), using a Leica420i scanning electron microscope.

\section{Results and discussion}

Based on the results of the phase analysis of the alloys of Dy-Ag-In system, the composition of the investigated compound was found to be $R E \mathrm{Ag}_{\sim 3} \mathrm{In}_{3}$, as for the $\mathrm{TbAg}_{3} \mathrm{In}_{3}$ compound [19]. The composition was confirmed by EDX analysis of the surface of the single crystal. Experimental data and the results of the X-ray synchrotron powder diffraction analysis (Fig. 1) and the X-ray $\left(\mathrm{Mo} \mathrm{K}_{\alpha}\right)$ single crystal diffraction analysis are shown in Table 1 . It should be noted that the powder specimen contained small amounts of $\operatorname{DyIn}_{3}$ (18.92 wt.\%) [24] and $\mathrm{Ag}_{7} \operatorname{In}_{3}$ (2.73 wt.\%) [25] (Fig. 1). The refined unit cell parameters determined from the synchrotron powder diffraction data (15.1472(2) ̊) agree well with the values reported in [17] $(15.17 \AA)$ for an alloy of composition $\mathrm{Dy}_{16} \mathrm{Ag}_{42} \mathrm{In}_{42} \quad$ (conventional X-ray powder diffraction data), but are slightly higher than those obtained from the single crystal data $(15.1010(1) \AA)$. This indicates the possible existence of a small homogeneity range. Testing of various models based on both single crystal and powder diffraction data allowed us to assign the $\mathrm{YbAg}_{2} \mathrm{In}_{4}$ structure type (space group Im-3) to the $\mathrm{DyAg}_{\sim 3} \mathrm{In}_{3}$ compound. The basic structure motif of these compounds is the same. However, part of the Wyckoff positions (12e and $12 d)$ that are occupied by In atoms in the structure of $\mathrm{YbAg}_{2} \mathrm{In}_{4}$ are in the $\mathrm{DyAg}{ }_{\sim 3} \mathrm{In}_{3}$ compound occupied by Ag atoms (Ag6, Ag7). This model (Table 2) yields lower reliability factors and more regular values of the thermal parameters, both in the isotropic (Table 2) and anisotropic approximations (Table 3). The atomic coordinates refined for Dy and In agree well for powder and single crystal data and correspond well to the respective parameters in $\mathrm{TbAg}_{3} \mathrm{In}_{3}$. The positional parameters and the site occupancy $(\approx 1)$ of the atoms Ag6 and Ag7 (Table 2) are practically the same for the Dy- (both powder and single crystal data) and Tb-compounds. The site 
Table 2 Atomic coordinates and isotropic displacement parameters for $\mathrm{DyAg}_{3.010} \mathrm{In}_{3}$ (synchrotron X-ray powder data - ${ }^{1}$ first row), DyAg ${ }_{2.853} \operatorname{In}_{3}$ (conventional X-ray single crystal data $-{ }_{2}^{2}$ second row) and $\mathrm{TbAg}_{3} \mathrm{In}_{3}$ (conventional X-ray single crystal data [19] $-{ }^{3}$ third row). Space group Im-3.

\begin{tabular}{|c|c|c|c|c|c|c|}
\hline Atom & $\begin{array}{l}\text { Wyckoff } \\
\text { position }\end{array}$ & Occ. & $x$ & $y$ & $z$ & $B_{\text {iso }}, \AA^{2}$ \\
\hline${ }^{1}$ Dy & $24 g$ & 1 & 0 & $0.1868(2)$ & $0.3032(2)$ & $0.39(9)$ \\
\hline${ }^{2}$ Dy & $24 g$ & 1 & 0 & $0.18611(9)$ & $0.3030(1)$ & $0.94(3)$ \\
\hline${ }^{3} \mathrm{~Tb}$ & $24 g$ & 1 & 0 & $0.19692(3)$ & $0.31391(3)$ & - \\
\hline${ }^{1} \mathrm{Ag} 1,2$ & $16 f$ & 1 & $0.1605(2)$ & $0.1605(2)$ & $0.1605(2)$ & $2.32(9)$ \\
\hline${ }^{2} \mathrm{Ag} 1,2$ & $16 f$ & $0.93(1)$ & $0.1624(2)$ & $0.1624(2)$ & $0.1624(2)$ & $1.87(4)$ \\
\hline${ }^{3} \mathrm{Ag} 1$ & $16 f$ & $\int 0.67(3)$ & $0.1652(3)$ & $0.1652(3)$ & $0.1652(3)$ & - \\
\hline${ }^{3} \mathrm{Ag} 2$ & $16 f$ & $0.33(3)$ & $0.1515(6)$ & $0.1515(6)$ & $0.1515(6)$ & - \\
\hline${ }^{1} \mathrm{Ag} 3$ & $24 g$ & $0.76(2)$ & 0 & $0.2380(4)$ & $0.0906(3)$ & $1.2(2)$ \\
\hline${ }^{1} \mathrm{Ag} 4$ & $24 g$ & $0.13(2)$ & 0 & $0.286(2)$ & $0.083(2)$ & $1.6(14)$ \\
\hline${ }^{2} \mathrm{Ag} 3$ & $24 g$ & {$[0.749(3)$} & 0 & $0.2469(3)$ & $0.0938(3)$ & $1.51(9)$ \\
\hline${ }^{2} \mathrm{Ag} 4$ & $24 g$ & $0.206(4)$ & 0 & $0.2224(11)$ & $0.0873(15)$ & $0.91(7)$ \\
\hline${ }^{3} \mathrm{Ag} 3$ & $24 g$ & $0.61(2)$ & 0 & $0.2507(4)$ & $0.0954(7)$ & - \\
\hline${ }^{3} \mathrm{Ag} 4$ & $24 g$ & $0.40(2)$ & 0 & $0.2273(6)$ & $0.0875(1)$ & - \\
\hline${ }^{\mathrm{I}} \mathrm{Ag} 5$ & $48 h$ & $0.15(2)$ & $0.0808(15)$ & $0.0569(12)$ & $0.1092(11)$ & $1.9(8)$ \\
\hline${ }^{2} \mathrm{Ag} 5$ & $48 h$ & $\int 0.086(1)$ & $0.0904(11)$ & $0.0172(10)$ & $0.0722(11)$ & $0.75(11)$ \\
\hline${ }^{2} \mathrm{Ag} 5{ }^{\prime}$ & $48 h$ & $0.053(3)$ & $0.091(2)$ & $0.055(3)$ & $0.054(2)$ & 1.1(4) \\
\hline${ }^{3} \mathrm{Ag} 5$ & $48 h$ & $0.16(1)$ & $0.0892(5)$ & $0.0254(6)$ & $0.0638(1)$ & - \\
\hline${ }^{1} \mathrm{Ag} 6$ & $12 e$ & 1 & $0.1975(4)$ & 0 & $1 / 2$ & $1.8(3)$ \\
\hline${ }^{2} \mathrm{Ag} 6$ & $12 e$ & 1 & $0.1911(2)$ & 0 & $1 / 2$ & $1.20(7)$ \\
\hline${ }^{3} \mathrm{Ag} 6$ & $12 e$ & 1 & $0.19237(7)$ & 0 & $1 / 2$ & - \\
\hline${ }^{1} \mathrm{Ag} 7$ & $12 d$ & 1 & $0.4092(4)$ & 0 & 0 & $1.3(2)$ \\
\hline${ }^{2} \mathrm{Ag} 7$ & $12 d$ & 1 & 0.4094(3) & 0 & 0 & $1.72(8)$ \\
\hline${ }^{3} \mathrm{Ag} 7$ & $12 d$ & 1 & $0.40988(8)$ & 0 & 0 & - \\
\hline${ }^{1} \mathrm{Ag} 8$ & $12 d$ & $0.29(2)$ & 0 & 0 & $0.2007(12)$ & $1.4(13)$ \\
\hline 2 & - & - & - & - & - & - \\
\hline 3 & - & - & - & - & - & - \\
\hline${ }^{1}$ In1 & $24 g$ & 1 & 0 & $0.3998(3)$ & $0.3477(3)$ & $1.6(2)$ \\
\hline${ }^{2} \operatorname{In} 1$ & $24 g$ & 1 & 0 & $0.4025(2)$ & $0.3462(2)$ & $1.40(5)$ \\
\hline${ }^{3} \operatorname{In} 1$ & $24 g$ & 1 & 0 & $0.40263(5)$ & $0.34672(5)$ & - \\
\hline${ }^{1} \operatorname{In} 2$ & $48 h$ & 1 & $0.2006(2)$ & $0.1180(2)$ & $0.3372(2)$ & $1.58(11)$ \\
\hline${ }^{2} \operatorname{In} 2$ & $48 h$ & 1 & $0.2026(1)$ & $0.1177(1)$ & $0.3398(1)$ & $1.73(4)$ \\
\hline${ }^{3} \operatorname{In} 2$ & $48 h$ & 1 & $0.20274(4)$ & $0.11760(4)$ & $0.33970(4)$ & - \\
\hline
\end{tabular}

splitting is typical for the $\mathrm{Ag} 3,4$ atoms for both compounds, however for the $\mathrm{Tb}$ compound the total occupancy was equal to 1 , whereas for the Dy compound it is slightly lower $(0.89$ for the powder diffraction data and 0.96 for the single crystal data). Only the refinement on single crystal diffraction data show site splitting for the Ag5 (Ag5') atoms for the DyAg ${ }_{\sim 3} \mathrm{In}_{3}$ compound, but the site occupancy 0.14 agrees well with the results obtained by X-ray powder diffraction and with the results for $\mathrm{TbAg}_{3} \mathrm{In}_{3}$. Another difference is observed for the $16 f$ position occupied by $\mathrm{Ag} 1$ atoms, which is split in the case of $\mathrm{TbAg}_{3} \mathrm{In}_{3}$, whereas splitting is not observed by either structure determination method for the DyAg ${ }_{\sim 3} \operatorname{In}_{3}$ compound. The powder diffraction analysis yielded a site occupancy less than 1 for $\mathrm{DyAg}_{\sim 3} \operatorname{In}_{3}$. Finally, an additional atom site was located based on the X-ray powder analysis: Ag8 in Wyckoff position $12 d$ with occupancy factor 0.29 .

The refinement of the crystal structure resulted in the composition $\mathrm{DyAg}_{3.010} \mathrm{In}_{3}$ for the powder diffraction data and DyAg ${ }_{2.853} \mathrm{In}_{3}$ for the single crystal data. The small deficiency in silver atoms found for the single crystal led to lower values of the cell parameters. Interatomic distances and coordination numbers of the atoms are presented in Table 4. 
Table 3 Anisotropic displacement parameters $\left(\AA^{2}\right)$ for DyAg $g_{3.010} \mathrm{In}_{3}$ (synchrotron X-ray powder diffraction) and DyAg ${ }_{2.853} \mathrm{In}_{3}$ (conventional X-ray single crystal diffraction).

\begin{tabular}{|c|c|c|c|c|c|c|}
\hline Atom & $B_{11}$ & $B_{22}$ & $B_{33}$ & $B_{12}$ & $B_{13}$ & $B_{23}$ \\
\hline \multicolumn{7}{|c|}{$\operatorname{DyAg}_{3.010} \mathrm{In}_{3}$} \\
\hline Dy & $0.49(15)$ & $0.37(14)$ & $0.3(2)$ & 0 & 0 & $-0.17(13)$ \\
\hline Ag1,2 & $2.32(15)$ & $2.32(15)$ & $2.32(15)$ & $0.4(2)$ & $0.4(2)$ & $0.4(2)$ \\
\hline Ag3,4 & $1.1(4)$ & $1.5(4)$ & $0.9(4)$ & 0 & 0 & $0.4(3)$ \\
\hline Ag6 & $2.2(4)$ & $1.4(4)$ & $2.0(4)$ & 0 & 0 & 0 \\
\hline $\mathrm{Ag} 7$ & $1.0(4)$ & $1.5(4)$ & $1.5(4)$ & 0 & 0 & 0 \\
\hline In1 & $1.6(3)$ & $1.4(3)$ & $1.9(3)$ & 0 & 0 & $-0.4(2)$ \\
\hline $\operatorname{In} 2$ & $1.3(2)$ & $1.9(2)$ & $1.5(2)$ & $0.3(2)$ & $-0.19(14)$ & $-0.3(2)$ \\
\hline \multicolumn{7}{|c|}{$\operatorname{DyAg}_{2.853} \mathrm{In}_{3}$} \\
\hline Dy & $0.86(5)$ & $0.88(4)$ & $1.08(5)$ & 0 & 0 & $-0.06(4)$ \\
\hline $\operatorname{Ag} 1,2$ & $1.87(6)$ & $1.87(6)$ & $1.87(6)$ & $1.29(8)$ & $1.29(8)$ & $1.29(8)$ \\
\hline Ag3,4 & $0.90(10)$ & $2.6(2)$ & $1.03(12)$ & 0 & 0 & $0.6(2)$ \\
\hline Ag6 & $0.86(11)$ & $0.92(11)$ & $1.82(12)$ & 0 & 0 & 0 \\
\hline $\mathrm{Ag} 7$ & $1.13(12)$ & $2.9(2)$ & $1.19(12)$ & 0 & 0 & 0 \\
\hline In1 & $1.48(8)$ & $1.38(8)$ & $1.33(8)$ & 0 & 0 & $0.04(6)$ \\
\hline In 2 & $1.46(6)$ & $2.38(7)$ & $1.37(5)$ & $0.60(5)$ & $-0.35(5)$ & $-0.43(5)$ \\
\hline
\end{tabular}

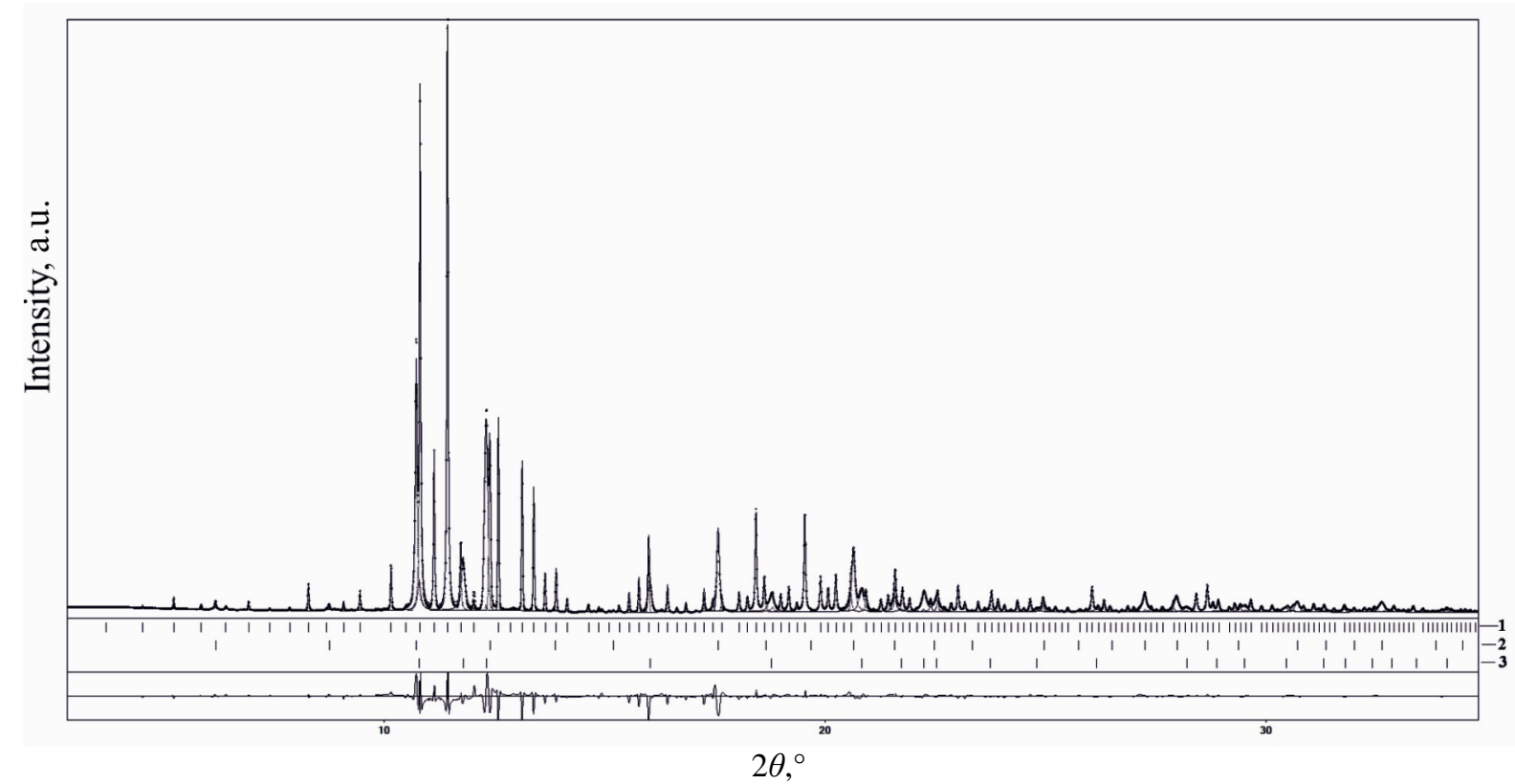

Fig. 1 Observed (circles), calculated (solid line) and difference diffraction patterns of the $\operatorname{Dy}_{15} \mathrm{Ag}_{43} \operatorname{In}_{42}$ alloy: $1-\mathrm{DyAg}_{3.010} \mathrm{In}_{3} ; 2-\mathrm{DyIn}_{3} ; 3-\mathrm{Ag}_{7} \mathrm{In}_{3}$. Synchrotron radiation, $\lambda=0.49063 \AA$.

The interatomic distances Ag-Ag within the coordination polyhedra range from $2.46(\mathrm{Ag} 4-\mathrm{Ag} 5)$ to $3.19 \AA$ (Ag6-Ag7), i.e. approximately $11 \%$ less and more than the sum of the atomic radii, respectively. The shortest distance In-In is $2.86 \AA$ (In2-In2) and the longest one is $3.56 \AA$ (In2-In2), i.e. also 10-12 \% less and more than the sum of the atomic radii [26]. The coordination polyhedra of the Dy atoms $(\mathrm{CN}=16)$ is a pentagonal prism with additional atoms capping all of the lateral faces and one base. The coordination numbers of the $\mathrm{Ag}$ atoms are 10 for $\mathrm{Ag} 1-\mathrm{Ag} 4,7$ for $\mathrm{Ag} 5,12$ for $\mathrm{Ag6}$, and 11 for $\mathrm{Ag} 7$, and correspond to coordination polyhedra in the form of trigonal prisms and derivatives of icosahedrons. The indium atoms have slightly higher coordination numbers, 12 for In 1 and In2 (Fig. 2).

\section{Conclusions}

Quasicrystals are extremely sensitive to different external influences (e.g. temperature). In the $\mathrm{YbCd}_{6}$ compound, one of the $\mathrm{Cd}$ atoms $(\mathrm{Cd} 2)$ occupies the position $24 g$ with occupancy $1 / 3$ at $90 \mathrm{~K}$, but $48 h$ with 
Table 4 Interatomic distances $(\delta, \AA)$ and coordination numbers $(\mathrm{CN})$ of the atoms in $\mathrm{DyAg}_{2.853} \operatorname{In}_{3}$.

\begin{tabular}{|c|c|c|c|c|c|c|c|c|c|c|c|}
\hline$\frac{\text { Atom }}{\text { Dy }}$ & \multicolumn{2}{|r|}{$\delta, \AA$} & $\frac{\mathrm{CN}}{16}$ & \multirow[b]{2}{*}{$\begin{array}{l}\text { Atom } \\
\text { Ag4 } \\
\text { (or } \\
\text { (or }\end{array}$} & \multicolumn{2}{|c|}{$\delta, \AA$} & $\frac{\mathrm{CN}}{10}$ & $\frac{\text { Atom }}{\text { Ag7 }}$ & \multicolumn{2}{|c|}{$\delta, \AA$} & \multirow{2}{*}{$\frac{\mathrm{CN}}{11}$} \\
\hline \multirow[t]{3}{*}{ (or } & $\begin{array}{l}2 \operatorname{In} 2 \\
1 \mathrm{Ag} 7 \\
2 \mathrm{Ag} 3 \\
2 \mathrm{Ag} 4 \\
2 \mathrm{Ag} 1,2\end{array}$ & $\begin{array}{l}3.180(2) \\
3.237(2) \\
3.259(3) \\
3.303(2)) \\
3.264(3)\end{array}$ & 16 & & $\begin{array}{l}1 \mathrm{Ag} 5 \\
1 \mathrm{Ag} 5 \\
1 \mathrm{Ag} 5 \\
1 \mathrm{Ag} 4 \\
1 \mathrm{Ag} 3\end{array}$ & $\begin{array}{l}2.46(4) \\
2.58(3)) \\
2.81(3)) \\
2.73(2) \\
2.77(2))\end{array}$ & 10 & Ag7 & $\begin{array}{l}\mathrm{Ag} 7 \\
2 \mathrm{Ag} 1,2 \\
4 \mathrm{In} 1 \\
2 \mathrm{Ag} 6 \\
2 \mathrm{Dy}\end{array}$ & $\begin{array}{l}2.736(5) \\
2.833(5) \\
3.071(3) \\
3.194(3) \\
3.237(2)\end{array}$ & \\
\hline & $\begin{array}{l}2 \operatorname{In} 2 \\
1 \mathrm{Ag} 1,2 \\
2 \operatorname{In} 2 \\
1 \operatorname{In} 1 \\
2 \operatorname{In} 1\end{array}$ & $\begin{array}{l}3.277(2) \\
3.290(5) \\
3.293(2) \\
3.333(3) \\
3.355(2)\end{array}$ & & & $\begin{array}{l}2 \mathrm{Ag} 1,2 \\
2 \mathrm{In} 2 \\
1 \mathrm{Ag} 7 \\
2 \mathrm{Dy} \\
1 \mathrm{Dy}\end{array}$ & $\begin{array}{l}3.06(2) \\
3.029(11) \\
3.077(11) \\
3.65(2) \\
3.65(2)\end{array}$ & & \multirow[t]{3}{*}{ In1 } & $\begin{array}{l}1 \mathrm{Ag} 6 \\
1 \mathrm{Ag} 6 \\
1 \operatorname{In} 1 \\
2 \operatorname{In} 2 \\
2 \operatorname{In} 2\end{array}$ & $\begin{array}{l}2.719(3) \\
2.766(4) \\
2.943(3) \\
2.945(2) \\
2.959(3)\end{array}$ & 12 \\
\hline & 1Ag6 & $3.506(2)$ & & Ag5 & $1 \mathrm{Ag} 4$ & $2.81(3)$ & 7 & & $2 \mathrm{Ag} 7$ & $3.071(3)$ & \\
\hline \multirow[t]{2}{*}{$\operatorname{Ag} 1,2$} & $\begin{array}{l}2 \operatorname{In} 2 \\
2 \mathrm{Ag} 5\end{array}$ & $\begin{array}{l}2.798(4) \\
2.56(3)\end{array}$ & 10 & (or & $\begin{array}{l}1 \mathrm{Ag} 3 \\
1 \mathrm{Ag} 4\end{array}$ & $\begin{array}{l}2.92(4)) \\
2.58(3)\end{array}$ & & & $\begin{array}{l}\text { 1Dy } \\
\text { 2Dy }\end{array}$ & $\begin{array}{l}3.333(3) \\
3.355(2)\end{array}$ & \\
\hline & $\begin{array}{l}1 \mathrm{Ag} 7 \\
2 \mathrm{Ag} 4 \\
2 \mathrm{Ag} 3 \\
2 \mathrm{Dy} \\
1 \mathrm{Dy}\end{array}$ & $\begin{array}{l}2.833(5) \\
2.65(2) \\
2.76(2)) \\
3.2595(3) \\
3.290(5)\end{array}$ & & $\begin{array}{l}\text { (or } \\
\text { (or } \\
\text { (or }\end{array}$ & $\begin{array}{l}1 \mathrm{Ag} 3 \\
1 \mathrm{Ag} 1,2 \\
2 \mathrm{Ag} 5 \\
2 \mathrm{Ag} 5 \\
1 \mathrm{Ag} 5\end{array}$ & $\begin{array}{l}2.92(4)) \\
2.56(3) \\
2.79(19) \\
3.10(4)) \\
2.74(4))\end{array}$ & & \multirow[t]{3}{*}{ In 2} & $\begin{array}{l}1 \mathrm{Ag} 1,2 \\
1 \mathrm{Ag} 8 \\
2 \mathrm{In} 2 \\
1 \mathrm{In} 1 \\
1 \mathrm{In} 1\end{array}$ & $\begin{array}{l}2.798(4) \\
2.828(3) \\
2.861(3) \\
2.945(2) \\
2.959(3)\end{array}$ & 12 \\
\hline $\begin{array}{l}\text { Ag3 } \\
\text { (or }\end{array}$ & $\begin{array}{l}2 \mathrm{In} 2 \\
1 \mathrm{Ag} 4 \\
1 \mathrm{Ag} 3 \\
1 \mathrm{Ag} 7 \\
1 \mathrm{Ag} 5 \\
1 \mathrm{Ag} 5 \\
1 \mathrm{Ag} 5 \\
2 \mathrm{Ag} 1,2\end{array}$ & $\begin{array}{l}2.869(5) \\
2.73(3) \\
2.744(7)) \\
3.12(2) \\
2.92(4) \\
3.04(4)) \\
3.36(2)) \\
2.76(2)\end{array}$ & 10 & $\begin{array}{l}\text { (or } \\
\text { (or } \\
\text { (or } \\
\text { (or } \\
\text { (or } \\
\text { (or }\end{array}$ & $\begin{array}{l}1 \mathrm{Ag} 5 \\
2 \mathrm{Ag} 5 \\
2 \mathrm{Ag} 5 \\
1 \mathrm{Ag} 5 \\
1 \mathrm{Ag} 5 \\
1 \mathrm{Ag} 4 \\
1 \mathrm{Ag} 3 \\
1 \mathrm{Ag} 1,2\end{array}$ & $\begin{array}{l}3.19(4)) \\
3.21(4)) \\
3.39(4)) \\
3.52(4)) \\
3.58(4)) \\
2.96(3) \\
3.04(4)) \\
3.03(3) \\
\end{array}$ & & & $\begin{array}{l}\text { 1Ag6 } \\
1 \mathrm{Dy} \\
1 \mathrm{Dy} \\
1 \mathrm{Dy} \\
1 \mathrm{In} 2 \\
1 \mathrm{Ag} 7\end{array}$ & $\begin{array}{l}3.007(2) \\
3.180(2) \\
3.277(2) \\
3.293(2) \\
3.555(3) \\
3.567(2)\end{array}$ & \\
\hline $\begin{array}{l}\text { (or } \\
\text { (or }\end{array}$ & $\begin{array}{l}2 \mathrm{Dy} \\
1 \mathrm{Dy}\end{array}$ & $\begin{array}{l}3.334(11) \\
3.30(2)\end{array}$ & & Ag6 & $\begin{array}{l}2 \operatorname{In} 1 \\
2 \operatorname{In} 1 \\
4 \operatorname{In} 2 \\
2 \mathrm{Ag} 7 \\
2 \mathrm{Dy}\end{array}$ & $\begin{array}{l}2.719(3) \\
2.766(4) \\
3.007(2) \\
3.194(3) \\
3.506(2) \\
\end{array}$ & 12 & & & & \\
\hline
\end{tabular}
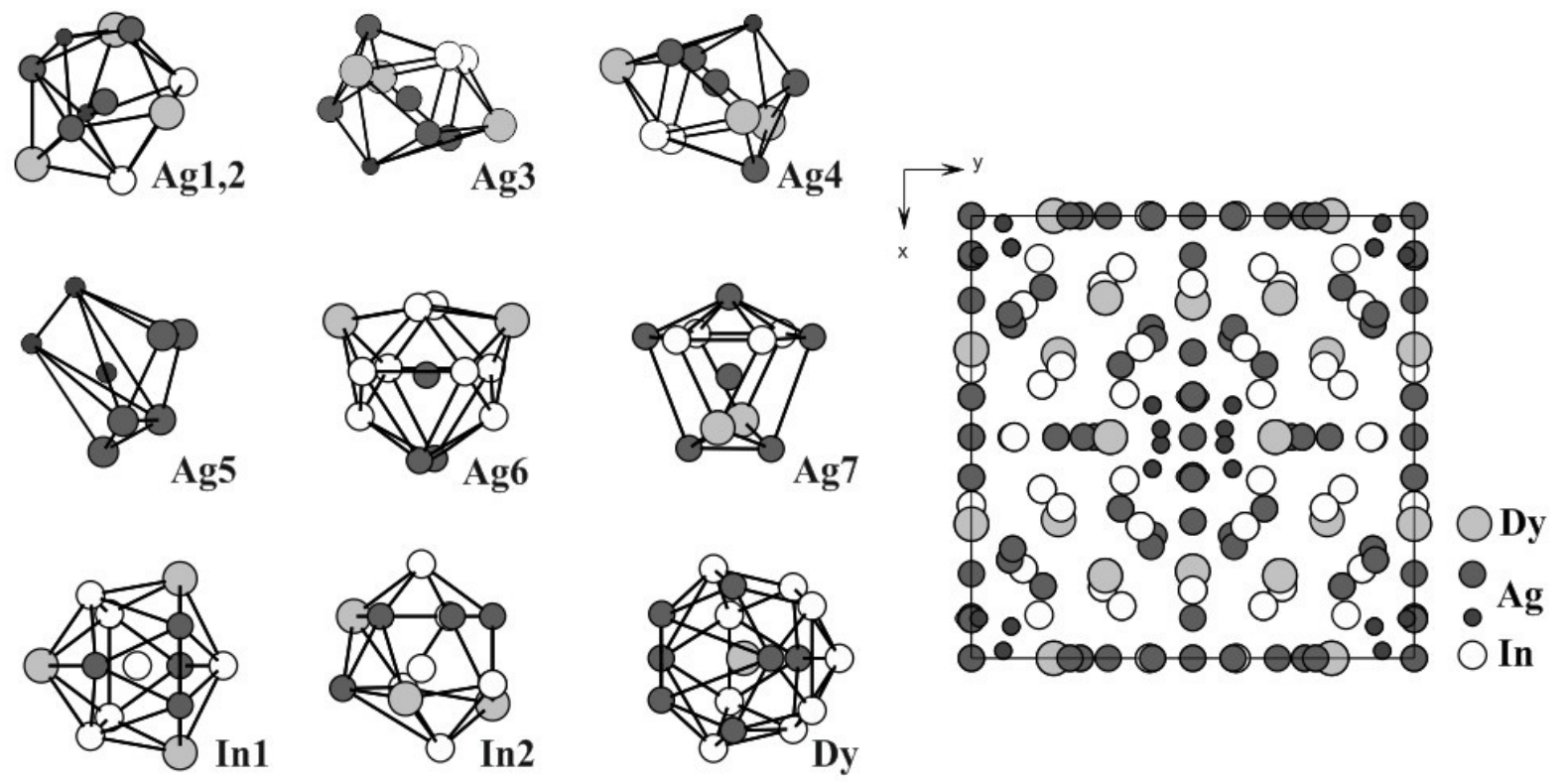

Fig. 2 Projection of the crystal structure of $\mathrm{DyAg}_{2.853} \mathrm{In}_{3}$ and the coordination polyhedra of the atoms (from $\mathrm{X}$-ray single crystal diffraction data). 
occupancy $1 / 6$ at $240 \mathrm{~K}$ [27]. Similar changes are observed for other $R E \mathrm{Cd}_{6}$ compounds, especially when $R E=\operatorname{Pr}$, Eu. In this case both the splitting of the atomic positions and their occupancies change [28]. Similar differences exist between the structures of $\mathrm{YbAg}_{2} \mathrm{In}_{4}$ [12], $\mathrm{TbAg}_{3} \mathrm{In}_{3}$ [19] and $\mathrm{DyAg}_{3.010} \mathrm{In}_{3}$ (or DyAg $2.853 \operatorname{In}_{3}$ ), although the basic structural motif remains unchanged.

\section{References}

[1] Ya.M. Kalychak, V.I. Zaremba, R. Pöttgen, M. Lukachuk, R.-D. Hoffmann, Handbook on the Physics and Chemistry of Rare Earths, Vol. 34, 2005, pp. 1-133.

[2] M. Giovannini, A. Saccone, P. Rogl, R. Ferro, Intermetallics 11 (2003) 197-206.

[3] M. Giovannini, A. Saccone, S. Delfino, P. Rogl, Intermetallics 11 (2003) 1237-1243.

[4] D.V. Shtepa, S.N. Nesterenko, A.I. Tursina, E.V. Murashova, Yu.D. Seropegin, Vestn. Mosk. Univ., Ser. Khim. 49 (2008) 197-202.

[5] L. Sojka, M. Daszkiewisz, B. Belan, M. Ivanyk, M. Manyako, Ya. Kalychak, Visn. Lviv Univ., Ser. Khim. 49 (2008) 137-144.

[6] L. Sojka, M. Daszkiewisz, B. Belan, M. Manyako, V. Davydov, L. Akselrud, Ya. Kalychak, Ukr. Khim. Zh. 74 (2008) 90-94.

[7] L. Sojka, M. Manyako, R. Cerny, M. Ivanyk, B. Belan, R. Gladyshevskii, Ya. Kalychak, Intermetallics 16 (2008) 1-4.

[8] A.I. Tursina, S.N. Nesterenko, Y.D. Seropegin, Acta Crystallogr. E 60 (2004) i64-i65.

[9] F. Hulliger, B.Z. Xue, J. Alloys Compd. 215 (1994) 267-270.

[10] V.I. Zaremba, D. Kaczorowski, U.Ch. Rodewald, R.D. Hoffman, R. Pöttgen, Chem. Mater. 16 (2004) 466-476.

[11] V.I. Zaremba, U.Ch. Rodewald, Ya.M. Kalychak, Ya.V. Galadgun, D. Kaczorowski, R.D. Hoffman, R. Pöttgen, Z. Anorg. Allg. Chem. 629 (2003) 434-442.
[12] L.V. Sysa, Ya.M. Kalychak, Ya.V. Galadzhun, V.I. Zaremba, L.G. Akselrud, R.V. Skolozdra, J. Alloys Compd. 266 (1998) 17-21.

[13] A.C. Larson, D.T. Cromer, Acta Crystallogr. B 27 (1971) 1875-1879.

[14] A. Palenzona, J. Less-Common Met. 25 (1971) 367-372.

[15] Ya.V. Galadzhun, Ya.M. Kalychak, V.I. Zaremba, J. Stępeń-Damm, A. Pietraszko, Proc. $4^{\text {th }}$ Int. Conf. f-elements, 2000, AP24.

[16] Ya.V. Galadzhun, Ya.M. Kalychak, J. StępeńDamm, A. Pietraszko, Coll. Abstr. $7^{\text {th }}$ Sci. Conf. Lviv. Khimichni Chytannya, 1999, p. 25.

[17] J.F. Ruan, K.H. Kuo, J.Q. Guo, An Pang Tsai, J. Alloys Compd. 370 (2004) L23-L27.

[18] Y.K. Kuo, K.M. Sivakumar, H.H. Lai, C.N. Ku, S.T. Lin, A.B. Kaiser, Phys. Rev. B: Condens. Matter 72 (2005) 054202.

[19] M. Demchyna, J. Stępeń-Damm, B. Belan, M. Manyako, Ya. Kalychak, Visn. Lviv Univ., Ser. Khim. 50 (2009) 144-149.

[20] Y. Morita, An Pang Tsai, Jpn. J. Appl. Phys. 47 (2008) 7975-7979.

[21] C.P. Gómez, Y. Morita, A. Yamamoto, An Pang Tsai, J. Phys: Conf. Ser. 165 (2009) 012045.

[22] A. Tursina, S. Nesterenko, E. Murashova, Z. Kurenbaeva, Y. Seropegin, Proc. $17^{\text {th }}$ Int. Conf. Solid Compounds of Transition Elements, 2010, p. 48.

[23] L.G. Akselrud, Y.N. Grin, P.Y. Zavalii, V.K. Pecharsky, V.S. Fundamenskii, Coll. Abstr. $12^{\text {th }}$ Eur. Crystallogr. Meet., 1989, p. 155.

[24] S.P. Yatsenko, A.A. Semyannikov, H.O. Shakarov, E.G. Fedorova, J. Less-Common Met. 90 (1983) 95-108.

[25] E. Hellner, Z. Metallkd. 42 (1951) 17-19.

[26] J. Emsley, The Elements. Clarendon Press, Oxford, 1991.

[27] S. Xia, S. Bobev, Intermetallics 15 (2007) 550556.

[28] C.P. Gómez, S. Lidin, Phys. Rev. B. 68 (2003) 024203. 